\title{
Exploring the Secrets of the Corona Virus: Gender Competition in Antibodies Production to Combat COVID-19
}

\author{
Hamzullah khan \\ Associate Professor Hematology, Department of Pathology, Nowshera Medical College Nowshera, Pakistan.
}

Corresponding Author: Dr Hamzullah khan, Associate Professor \& Director Research \& Development, Nowshera Medical College, Phone: 0334-4802902.

Received date: September 05, 2020; Accepted date: October 15, 2020; Published date: December 07, 2020

Citation: H khan. (2020) Exploring the Secrets of the Corona Virus: Gender Competition in Antibodies Production to Combat COVID-19. General medicine and Clinical Practice. 3(3); DOI: 10.31579/2639-4162/036

Copyright: ๑ 2020 Hamzullah khan, This is an open-access article distributed under the terms of the Creative Commons Attribution License, which permits unrestricted use, distribution, and reproduction in any medium, provided the original author and source are credited.

\begin{abstract}
:
We did a pilot study in the month of July 2020 in Qazi Hussain Ahmed Medical complex Nowshera with aim to determine the gender protective role in term of production of neutralizing Anti SARS-COV-2 antibodies. A total of 39 COVID-19 patients with recovery were selected and their antibodies cut off values were measured by electro-chemiluminescence immunoassay using Roche Cobas E411 Chemistry Analyzer for which commercial kits of Roche diagnostics were used as per the instructions of the manufacturer. It was observed that Difference in mean post infection antibodies level was statistically significant with higher cut off values in patient who had symptoms at time of being reported positive by PCR as compared to patient who were asymptomatic (pvalue:0.04). We predicted using Kaplan Meir that female gender the probability of survival as $70 \%$ in with cut off values of 100 , while a vertical drop up to less than $20 \%$ probability of survival was predicted in male gender. Hence female gender produces higher level of antibodies in early infections to confer immunity in COVID-19.

Key words: COVID-19; survival; pandemic
\end{abstract}

\section{Introduction:}

According to the World Health Organization, the viral diseases are continue to emerge and are representing serious health issues in time and future. The outbreak in 2019 was totally different with presentation of pneumonia of unknown cause, later on the Chinese Centre for Disease Control and Prevention and local CDC attributed it to a novel virus belonging to corona family and was termed as 2019-nCoV. That was first reported from the city of Wuhan in China [1, 2]. The demographic variables like gender and age play an important role in prognosis and outcome of COVID-19. This deadly disease is striking and killed more Italian males as compared to females in extreme of age because of their weak immunity status. The same observations were reported in China with more causality in male gender and at extreme age [1,3]. Males and female genders have the same prevalence but the severity of the disease was markedly higher in male gender with worst outcomes and death [4]. Pakistan is not an exception and we published on the impact of demographic variable in COVID-19. We observed that the infection rate was 1.25 times more in males than females without significant $p$ value $(\boldsymbol{O R}=\mathbf{1 . 2 5})$. The case fatality rate was $5.41 \%$ in our population. The infection was more common in younger age and mortality was more in older age irrespective of gender $(\boldsymbol{p}=\mathbf{0 . 0 1 4})$ [5]. Many factors could contribute for gender differences including low viral load in females because of less exposure as compared to the male gender in our religious society. Some of the scientists are of the opinion that the number of death reported are caused by the gender behavior (life style) i.e. smoking, drinking and working abroad are more among men as compared to women [6]. The IgG antibodies production in mild, moderate and severe COVID19 in female gender tends to rise promptly as compared to males which may account for different outcome of COVID-19 [7]. Present pilot study was conducted to assess the role of covid-19 antibodies expression in gender groups to predict the gender protection and surviving in the current pandemic in a hospital based pilot study.

\section{Material and methods:}

To quantify the role of antibodies production in gender groups in corona infection we did a cross sectional study covering 39 patients who were tested positive in Qazi Hussain Ahmed Medical Complex Nowshera, Pakistan in the month of July 2020. The criteria for selection of the candidates was that only those patients who were reportedly negative on PCR for 2019-nCoV done 3 week ago, were included for their antibodies status.

Data was entered in SPSS 25 version. Independent t test was used to determine the difference of neutralizing antibodies in positive patient with or without symptoms at time of infection. Kaplan Meir test was used to predict the probability of survival in age and gender groups based on the antibodies levels.

\section{Results and Discussion:}

Difference in mean post infection antibodies level irrespective of gender was statistically significant with higher cut off values in patient who had symptoms at time of being reported positive by PCR as compared to patient who were asymptomatic (p-value: 0.04) (Table 1).The clinical presentation and immune response of symptom free individual infected with Corona virus have not been well reported in the literature. The study from China reported that patients infected with COVID-19 without having any obvious symptoms had significantly lower virus specific IgG 
antibodies (median S/CO, 3.4; IQR, 1.6-10.7) as compared to the symptomatic group (median S/CO, 20.5; IQR, 5.8-38.2) thatstrongly matches our findings. They reported their data with median probably due to scattered distribution [7].

Table 1. Clinical presentation at time of infection and its association with post infection antibodies levels.

\begin{tabular}{|c|c|c|c|}
\hline Clinical presentation & Number & $\begin{array}{l}\text { Mean +SD of anti } \\
\text { SARS-COV-2 } \\
\text { Antibodies }\end{array}$ & $\mathrm{p}$-value (Independent $\mathrm{t}$ test) \\
\hline Clinically asymptomatic & $22(56.41 \%)$ & $22+2.4$ & \multirow[t]{2}{*}{0.04} \\
\hline With symptoms/hospitalized & $17(43.58 \%)$ & $47+7.3$ & \\
\hline Total & \multicolumn{3}{|l|}{39} \\
\hline
\end{tabular}

From the above assumption in table 1, we came to know that a higher level of antibodies was statistically significantly supportive of the prediction that the patient might have had symptoms/hospitalization at time of diagnosis being victim of COVID-19. The levels of antibodies and duration of immunity after infection provides shield immunity to the patients and is a measure of better outcome [8].

We tried to predict the survival in gender group based on the post

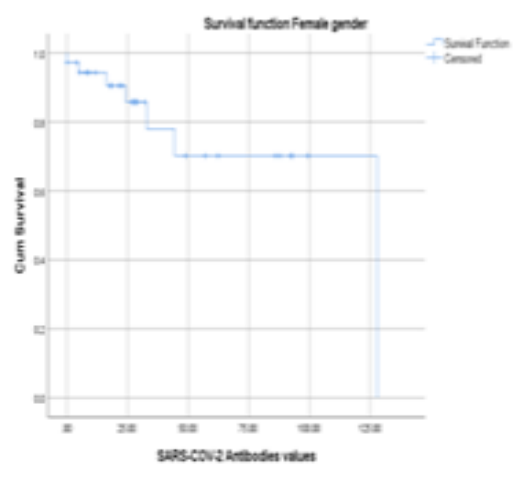

Fig 2. Gender competition for survival in sever infection

Studies do support these findings and from china they have reported 2.4 times higher mortality in males as compared to females, while the susceptibility for infection was almost equal in both the genders [9]. Many assumptions are floating that why female gender is more protective in viral disease specially COVID-19, some suggest a high plasma concentration of retonavir and high cholesterols high density lipoproties have been reported in females that confer immunity in COVID-19 [10]. Other quoted high levels of sex hormones and expression of angiotensin converting enzyme-2 (ACE-2) in men along with life style such as smoking and drinking among men as compared to women [6].

Hence by observing the outcome of COVID-19 in men demands for attention to move forward for treatment based on gender basis, future studies to address sex differences in morbidity and mortality due to Covid-19, as the virus behaves differently in both genders [11] Conti P et al reported the genetic basis in the support of female gender being more protective that $\mathrm{X}$ Chromosome influences the immune system by acting on many proteins like TLR8,CD40L and CXCR3 which are expressed in female gender that influence response to this deadly viral infection [12].

Hence we concluded that female gender is more protective offers more resistance to the $2019 \mathrm{n} \mathrm{CoV}$ infection as compared to the male gender with worst outcome in the form of case fatality. infection antibodies cut off values and we observed using Kaplan Meir that female gender the probability of survival was $70 \%$ predicted in severe infection with post infection antibodies even with cut off values of 100 , while a vertical drop up to less than $20 \%$ probability of survival was predicted in severe infection with post infection antibodies level of up to 127. This confers female gender being more protective with higher capacity of survival even in severe cases of Covid-19. (Fig 2)

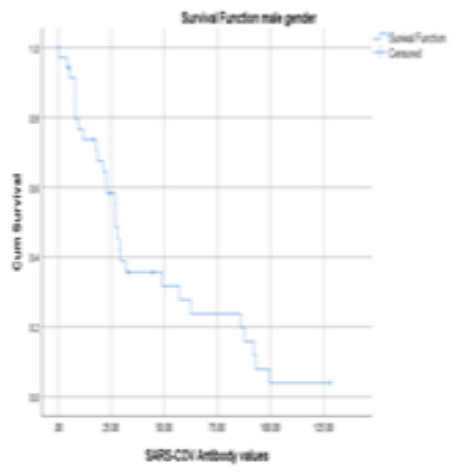

Therefore we recommend that there is need to better understanding the impact of gender in COVID-19 and to tailor the treatment according to the gender perspective and stressed the therapeutic trials must include gender sensitive analysis.

\section{Reference:}

1. Cascella M, Rajnik M, Cuomo A, et al. (2020) Features, Evaluation and Treatment Coronavirus (COVID-19) [Updated 2020 Mar 20]. In: StatPearls [Internet]. Treasure Island (FL): StatPearls Publishing.

2. Chen N, Zhou M, Dong X, Qu J, Gong F, Han Y. et al. (2020) Epidemiological and clinical characteristics of 99 cases of 2019 novel coronavirus pneumonia in Wuhan, China: a descriptive study. Lancet. 395:507-513.

3. World Health Organization. (2020) 2019-nCoV outbreak is an emergency of international concern.

4. Jin JM, Bai P, He W, et al. (2020) Gender Differences in Patients With COVID-19: Focus on Severity and Mortality. Front Public Health.

5. Khan, H., Hussain, S., zar, A., fawad, S. (2020) Analysis of demographic variables in acquiring infection and mortality due to COVID-19. Microbes and Infectious Diseases. 1(2): 70-76. 
6. Bwire GM. (2020) Coronavirus: Why Men are More Vulnerable to Covid-19 Than Women? SN Compr Clin Med. 2020; 1-3.

7. Long, Q., Tang, X., Shi, Q. et al. (2020) Clinical and immunological assessment of asymptomatic SARS-CoV-2 infections. Nat Med 26, 1200-1204.

8. Weitz, J. S., et al. (2020) Modeling shield immunity to reduce COVID-19 epidemic spread. Nat. Med.

9. Zhang JJ, Dong X, Cao YY, Yuan YD, Yang YB, Yan YQ, Akdis CA, Gao YD. (2020) Clinical characteristics of 140 patients infected with SARS-CoV-2 in Wuhan, China. Allergy. Jul; 75(7):1730-1741.
10. Shiau S, Kuhn L, Strehlau R, Martens L, McIlleron H, Meredith S, et al. (2014) Sex Differences in responses to antiretroviral treatment in South African Hiv-infected children on ritonavirboosted lopinavir- and nevirapine-based treatment. BMC Pediatr.

11. Elgendy IY, Pepine CJ. (2020) Why women are better protected from COVID-19: Clues for men? Sex and COVID-19. Int J Cardiol. 315:105-106.

12. Conti P, Younes A. (2020) Coronavirus COV-19/SARS-CoV2 affects women less than men: clinical response to viral infection. J Biol Regul Homeost Agents. 34(2):339-343.
This work is licensed under Creative Commons Attribution 4.0 License

To Submit Your Article Click Here: Submit Manuscript

DOI: $10.31579 / 2639-4162 / 036$
Ready to submit your research? Choose Auctores and benefit from:

* fast, convenient online submission

* rigorous peer review by experienced research in your field

* rapid publication on acceptance

* authors retain copyrights

* unique DOI for all articles

* immediate, unrestricted online access

At Auctores, research is always in progress.

Learn more www.auctoresonline.org/journals/general-medicine-andclinical-practice 